\title{
ПРИВАТИЗАЦИЯ МИРОВОЙ ПОЛИТИКИ
}

Карпович О.Г.

DOI: $10.7256 / 2305-560 X .2016 .4 .21286$

\section{ФУНКЦИИ НЕГОСУДАРСТВЕННЫХ УЧАСТНИКОВ МЕЖДУНАРОДНЫХ ОТНОШЕНИЙ}

\begin{abstract}
Аннотация. Настоящая статья посвящена исследованию функций негосударственных участников международных отношений - «акторов вне суверенитета», играющих сегодня ключевую роль в мировой политике. $K$ этой категории акторов относятся неправительственные организации, НКО, международные фонды, международные профессиональные объединения, транснациональные корпорации. Помимо конкуренции с традиционными акторами системы международных отношений - национальными государствами и межправительственными международными организациями, негосударственные акторы исполняют в современной системе мировой политики особые функции, обеспечивающие ее устойчивость, динамичность и способность к модернизации. Объектом исследования выступает мировая политика в целом, предметом исследования функции негосударственных участников международных отношений и мировой политики. Цель исследования - выявление и классификация функций негосударственных участников международных отношений и мировой политики. Методологической базой исследования выступает системный, институциональный, структурно-фрункциональный и сравнительно-политический подходы, методы анализа, синтеза, индукции, дедукции, наблюдения. Негосударственные участники международных отношений и мировой политики выполняют в политической сфере особые и совершенно определенные функции. Именно благодаря этому функционалу, характерному для негосударственных акторов, "акторов вне суверенитета», и несвойственных традиционным акторам международных отношений (в первую очередь, нациям-государствам) ТНК и занимают в мировой политике устойчивое положение, имеют свою политико-экологическую нишу.

Ключевые слова: политическая система, глобальное информационное пространство, мировая политика, внешняя политика США, международные отношения, самоорганизация, интересы, государство, безопасность, риски. Abstract. The paper studies the functions of non-state actors of international relations - "actors beyond sovereignty" playing the key role in the modern world politics. This category includes nongovernmental organizations, non-profitable organizations, international funds, international professional unions, transnational corporations. Besides competing with traditional actors of international relations - national states and international organizations - non-state actors have special functions in the modern world politics, which ensure its sustainability, dynamics and ability to modernize. The research object is global politics in general, the research subject is the functions of non-state actors of international relations and world politics. The research methodology is based on the system, institutional, structural and functional and comparative-political approaches, the methods of analysis, synthesis, induction, deduction and observation. Non-state actors of international relations and world politics have their special and definite functions in the political sphere. Owing to these functions, typical for non-state actors, "actors beyond sovereignty", and unusual for traditional actors of international relations, transnational corporations hold their stable position and political and ecological niche in global politics.
\end{abstract}

Key words: self-organization, international relations, U.S. foreign policy, world politics, global information space, political system, interests, state, security, risks.

$\mathrm{B}$ настоящее время внимание международного научного сообщества в значительной степени приковано к исследованию функционала негосударственных акторов (участников) международных отношений, благодаря которому они играют заметную роль в регулировании мирополитических процессов. Негосударственные акторы международных отношений (НГА), «вторгаясь» в сферу мировой политики и становясь регулятором мирополитических процессов, начинают взаимодействовать с международной средой, характер которого определяется (по П.А. Цыганкову) следующим рядом факторов: «стремлением к удовлетворению своих интересов; улучшением или ухудшением условий деятельности (внутренних и внешних); принуждением со стороны международной институциональной системы (уровень правил игры); культурной, этической, ценностной моделью, которая выражает идентичность актора» [1]. ТНК при этом полностью вписываются в приведенную выше мотивационную модель: они стремятся удовлетворить свои бизнес-интересы, связанные с увеличением прибыли при одновременной минимизации издержек, используя при этом не совсем привычные для них инструменты политического воздействия и регулирования; в зависимости от способности корпорации адаптироваться к особым условиям политической дея- 
тельности, это ведет либо к улучшению, либо к ухудшению условий их существования (как внешних, так и внутренних, поскольку обе эти сферы жизнедеятельности ТНК, как и любой другой корпорации или бизнес-системы, тесно взаимосвязаны). В ответ на «вторжение» в сферу собственных интересов «чужеродного» (с вестфальской точки зрения) элемента - ТНК - международная среда начинает на это «вторжение» реагировать, стремясь принудить новый вид акторов (ТНК) действовать по принятым в этой среде правилам игры. В ответ ТНК, частично подстраиваясь под уже существующие правила, начинает активно генерировать новые, опираясь на свои собственные корпоративные ценности, собственные подходы к выстраиванию и регулированию международных отношений, основанные на принципах проектной деятельности, принятой в крупном бизнесе, - то есть перестраивает политическую среду под себя. В результате международная среда демонстрирует определенную пластичность и начинает трансформироваться под влиянием глобальных и транснациональных корпораций, которые в данном случае выступают одним из факторов ее модификации. В этом заключается одна из функций ТНК как «актора вне суверенитета», которую ТНК привносят в мировую политику.

Функции негосударственных акторов в мировой политике напрямую связаны с той ролью, которая им отводится в этой сфере традиционными акторами МО - нациями-государствами. Однако только этим функционал «акторов вне суверенитета» не ограничивается: феномен массового «вторжения» НГА в мировую политику ведет к тому, что у «акторов вне суверенитета» появляются собственные, в определенном роде эксклюзивные функции в сфере политики.

Вряд ли можно оспорить тезис о том, что НГА, включившись в регулирование политических отношений и процессов, должны выполнять в политической сфере те же функции, что и любые другие (традиционные) политические акторы. Однако, эта сфера уже занята нациями-государствами, которые не спешат уступать ее новым негосударственным участникам. В Вестфале возможность осуществлять внешние сношения целиком зависит от обладания суверенитетом, который есть у государств и который отсутствует у НГА. В этой связи политические права, возможности и компетенция НГА целиком зависят от того, делегируют ли им (на время или на постоянной основе) национальные государства определенный объем международной правосубъектности. Складывается ситуация, при которой НГА, действующие в поле и по законам Вестфальской системы, вынуждены каждый раз получать определенного рода «мандат». Это в полной мере касается и ТНК, стремящихся утвердиться в сфере мировой политики и совершать в ней юридически значимые действия.

С другой стороны, проникновение НГА в мировую политику связано с компенсационным эффектом: НГА привлекаются национальными правительствами для решения тех проблем, которые сами национальные государства, в силу ряда их специфических особенностей (наличия территории, четко очерченных национальными границами, неделимого суверенитета и особого положения в Вестфальской системе), преодолеть не в состоянии. Например, НГА часто используются в посреднических целях; при этом НГА могут играть роль как активного участника переговоров, агента нации-государства (стороны, представляющей ее интересы и наделенной соответствующими полномочиями), международного посредника или даже арбитра, так и площадки для проведения переговоров. В этом смысле для конфликтующих государств использование НГА в качестве посредника или переговорной площадки во многих случаях является весьма удобным, так как привлечение в аналогичной ситуации другого национального государства может привести к включению в конфликт нового участника, способного использовать свое преимущественное положение в собственных корыстных целях или использовать свой политический статус и вес для того, чтобы обеспечить перевес в переговорах одной из сторон конфликта, обладающей с медиатором полностью или частично совпадающими национальными интересами. НГА же, будучи по своей природе «акторами вне суверенитета», ни собственной государственной территорией, ни государственным суверенитетом не обладают и, следовательно, не испытывают желания отобрать и то, и другое у одной из конфликтующих сторон. При выборе площадки для ведения переговоров НГА, как правило, воспринимаются конфликтующими государствами как «нейтральная территория», сам выбор которой не дает дополнительных преимуществ ни одной из сторон - что способствует сближению и конструктивному ведению переговоров.

НГА нередко привлекаются к участию в международных конфликтах на правах косвенного субъекта - их привлекают к реализации миротворческих миссий в части логистической, снабженческой, информационной поддержки деятельности миротворческих сил и гуманитарных миссий. Прямое участие НГА в международных конфликтах также возможно - если речь идет о нелегитимных НГА; что касается легитимных, то они обычно играют роль наблюдателей, посредников или международных агентов. При этом в международном конфликте, представляющим собой столкновение двух и более разнонаправленных политических 
сил по поводу власти и политического управления, НГА не воспринимаются традиционными акторами МO (прежде всего, нациями-государствами) как претендент на предмет спора - власть, что оставляет для НГА широкое пространство выбора тех или иных стратегий поведения в конфликте, дающее им довольно весомое конкурентное преимущество перед традиционными политическими акторами. Другими словами, в международных конфликтах, имеющих собственную структуру, систему и логику развития, НГА имеют право «играть не по правилам», что позволяет им преодолевать барьеры, непреодолимые для наций-государств.

Особую роль в современных международных конфликтах играют частные военные компании, многие из которых (например, группа компаний Academi) построены по принципу международных или транснациональных корпораций. ЧВК действуют по заказу национальных правительств, заключая с ними контракты на охрану и сопровождение грузов (как гражданского, так и военного назначения), охрану караванов, судов, военных баз, гуманитарных, дипломатических миссий, политических лидеров, в отдельных случаях берут на себя решение задач контрпартизанской, контрдиверсионной и контртеррористической борьбы. На деле же ЧВК непосредственно участвуют в боевых действиях в зонах конфликтов, подавляют сопротивление противника, уничтожают его базы и каналы снабжения, проводят «рейды возмездия» и карательные операции, ведут разведку и контрразведку. В Афганистане и Ираке большая часть военных операций приходилась на долю ЧВК; в гражданской войне на Донбассе неоднократно отмечалось участие на стороне Украины иностранных наёмников из американских и польских ЧВК; в Сирии на стороне Асада сегодня выступают частные иранские военные компании (в провинции Алеппо). По данным экспертов, «в военном конфликте в Ираке число персонала частных военных компаний оценивалось в диапазоне от 20 до 30 тысяч человек, что делает частных военных вторым по величине контингентом в Ираке после американских войск. Кроме того, около 10 тысяч контрактников действовало в Афганистане, включая местных граждан, граждан других стран и персонала компаний, обеспечивающих безопасность в Афганистане» [2]. ЧВК в этих условиях не просто становятся инструментом реализации национальными государствами своей внешней политики в зонах вооруженных конфликтов, выполняя те задачи, которые не очень удобно возлагать на национальные вооруженные силы (например, устранение военных лидеров противника, диверсии, репрессии, проведение контрпартизанских и карательных акций, нелегальная поддержка и об- учение повстанческих формирований), но и приобретают самостоятельное значение среди непосредственных участников конфликтов. Национальные правительства охотно пользуются услугами ЧВК, так как их боевые контингенты можно использовать в прокси, гибридных и необъявленных войнах, без риска быть обвиненными в вооруженном вмешательстве во внутренние дела государств, на территории которых разворачивается гибридная война; по мнению Ф. Франциони, «возможность призвания государства к ответственности за действия ЧВОП остаются достаточно ограниченными» [3]. Кроме того, ЧВК, в отличие от национальных армий демократических стран, не чувствительны к потерям, поскольку в ЧВК проходят службу наемники со всего света и, в случае потерь, их всегда можно восполнить за счет новых наемников. Потери же в национальных армиях вызывают бурю протеста среди населения демократических стран, которое сразу начинает требовать прекращения военных операций за пределами страны и вывода войск из зон зарубежных конфликтов. По мнению журнала «The Economist», «ЧВК - это альтернатива государству там, где государство не эффективно или не может действовать официально, направляя войска. Их использование решает проблему общественного недовольства, которое может вызывать применение регулярных вооруженных сил» [4].

В свою очередь, ЧВК пользуются своим привилегированным политическим положением и часто заявляют о себе как об интернационализированной политической силе, способной выступать на международной арене как самостоятельно, так и в союзе с нациями-государствами. Для этого есть определенные основания: крупные транснациональные ЧВК, такие как Academi (бывшая Black Water) обладают совокупным военным потенциалом, сопоставимым с военным потенциалом некоторых азиатских и африканских государств, и превосходящим их по мобильности, скорости развертывания, качестве боевой подготовки и ресурсной базе, включающей механизмы восполнения боевых и небоевых потерь. Однако именно международные деятельность ЧВК становится объектом крупных скандалов и предметом разбирательств международных уголовных судов: «осенью 2007 года подрядчики из ЧВК «Blackwater» попали под огонь критики за убийства 17 мирных иракцев во время обеспечения мобильной защиты конвоя сотрудников USAID; во время проведения специальных операций в Африке ЧВК «Executive Outcomes» была подвергнута критике за использование кассетных бомб и других военных методов, противоречащих международному гуманитарному праву; в контексте участия ЧВОК в оккупации Ирака, частные подрядчики, нанятые в качестве следовате- 
лей, были уличены в применении крайних форм насилия по отношению к заключенным в тюрьме «Абу Грейб»» [5]. Это дает полное право противникам усиления роли ЧВК в мировых политических процессах поднимать вопрос о законности деятельности этих корпораций и их соответствия нормам международного права, а также о том, что современные ЧВК, возможно, являются завуалированной формой наемничества.

Кроме того, в случае с транснациональными ЧВК возникает пролема с их сращиванием с нелегальными организациями и группировками: экстремистами, террористами, организованной преступностью, которые также могут иметь транснациональный характер. Так, по утверждению военного эксперта Н. Башкирова, «значительные суммы от выплат по контрактам ЧВК уходили полевым командирам движения Талибан, выступившим в роли своего рода субподрядчиков проектов. ЧВК платили полевым командирам за безопасность перевозок по линиям коммуникаций грузов, которые они конвоировали и охраняли. По официальным данным, талибы через посредников получили из бюджета США около 360 млн долларов. Эти суммы составили второе место среди основных источников финансирования моджахедов после доходов от наркоторговли» [2].

Становясь политическим актором, НГА (и ТНК, в первую очередь), начинают выделяться следующими отличительными качествами: наличием политической воли к международному сотрудничеству, зафиксированной в учредительных или внутренних нормативных документах; наличием постоянного аппарата, обеспечивающего выполнение негосударственным актором специальных политических функций (в сфере мировой политики) и политическую преемственность на всех этапах эволюции формы существования НГА; автономностью компетенции и решений. Особенно это касается ТНК, которые в своем организационно-структурном виде и по формам и методам деятельности наиболее близки к межправительственным международным организациям (МПМО), три основные черты которых именно в данном контексте описал французский ученый Ш. Зоргбиб [6]. Действительно, ТНК весьма напоминают МПМО: также как и МПМО, ТНК имеют транснациональный характер и объединяют под своей эгидой различного рода международные силы, среди которых есть и политические; по структуре это объединение и в МПМО, и в ТНК напоминает холдинг (в международной сфере этот принцип союзного объединения называется федеративным). Поэтому и функции ТНК и МПМО во многом схожи. На это, отчасти, указывает А.Е. Кутейников, раскрывая с помощью методов социологического анализа «двойственную природу» ММПО, роднящую их с
НГА: по мнению ученого, с одной стороны, «ММПО являются союзами суверенных государств в форме постоянно действующей конференции»; с другой стороны, они образуют «сложный комплекс социальных отношений между людьми, создавшими их и обслуживающими» [7]. Благодаря этой двойственности деятельность, функционал (как внутренний, так и международный), структура, строение МПМО, протекание в них организационных процессов приобретают определённую специфику, сближающую МПМО с негосударственными акторами международных отношений и мировой политики, делая их очень похожими.

Единственное, чем ТНК, в отличие от МПМО, не обладают, это -суверенитет, поскольку ТНК не являются формой союзного объединения национальных государств, транснациональные корпорации - это «акторы вне суверенитета». Впрочем, отсутствие суверенитета, которым так дорожат нации-государства, не мешает ТНК заниматься регулированием региональных и даже глобальных мирополитических процессов.

В этой связи обращает внимание сходство функций, выполняемых МПМО и ТНК, несмотря на их принципиальные различия в природе и статусе. Так, к международным функциям МПМО относят: нормотворческую, контрольную, посредническую, консультативную, оперативную и информационную.

Нормотворческая функция МПМО состоит в участии МПМО в выработке и принятии правил поведения участников международных отношений и мировой политики.

Контрольная функция МПМО выражается в способности этой категории организаций давать оценку фактическому положению дел в системе международных отношений и мировой политики в соответствии с избранной (установленной самими участниками МО - учредителями или членами MПМО) системой правовых норм и критериев.

Посредническая функция МПМО заключается в реализации посреднических миссий, медиации, арбитраже либо в предоставлении своих площадок для ведения международных переговоров.

Консультативная функция МПМО состоит в аналитическом и экспертном сопровождении международной деятельности государств, являющихся учредителями или состоящих членами или наблюдателями в МПМО, политическом консультировании (по предметам ведения МПМО) как национальных правительств, национальных правительственных организаций, так и отдельных лиц, к которым могут относиться главы государств либо их законные представители. Подобного рода консультации представляют собой «взаимную передачу информации и состоят из нескольких фаз: 
фазы сопоставления, во время которой участники консультаций предоставляют информацию об их интересах, позициях, мнениях; фазы переговоров; фазы принятия рекомендаций организацией» [7].

Оперативная функция выражается в решении задач быстрого реагирования на чрезвычайные ситуации и оказания помощи терпящим бедствие государствам, народам, социальным группам, опираясь на имеющиеся в распоряжении МПМО собственные ресурсы и возможности. По мнению А.В. Кутейникова, «особое значение оперативные функции принимают в операциях $\mathrm{OOH}$ по поддержанию мира» [7].

В свою очередь, информационная функция МПМО заключается в том, что в системе мировой политики ММПО являются важнейшей составляющей международного (глобального) информационного обмена, способствуют установления политической медиакратии, довольно часто являются крупнейшими потребителями, транзитерами и каналами передачи информации.

Несложно убедиться в том, что по своему функционалу в системе международных отношений и мировой политики ТНК, фактически, совпадают с функциями МПМО. Это означает, что в политической сфере негосударственные акторы ТНК могут играть такую же роль, что и МПМО, и готовы занять их политическую нишу.

С другой стороны, ТНК по своему функционалу очень близки к неправительственным международным организациям (НПМО), представляющим собой другой вид негосударственных акторов международных отношений и мировой политики, «акторов вне суверенитета». Это действительно так: ТНК и НПМО принадлежат к одной группе негосударственных акторов, их объединяют многочисленные общие видовые и родовые признаки. Принципиальная же разница между ними состоит в одном: международные неправительственные организации - это «объединения национальных общественных организаций, союзов, групп и отдельных лиц из различных государств, созданных в целях содействия международному сотрудничеству в политической, экономической, культурной, научно-технической и других сферах деятельности человека; эти организации учреждены не на основании межправительственного соглашения и не ставят целью извлечение коммерческой прибыли» [16]; ТНК же созданы специально для извлечения коммерческой прибыли из любых проектов (в том числе политических), это - коммерческие акторы. Это различие хотя и носит принципиальный характер, но все же не создает непреодолимую пропасть между ТНК и НПМО: они действительно очень похожи (структурно, функционально) и ведут себя в системе мировой политики очень похоже. В этой связи существует тенденция объединять ТНК и НПМО в один вид НГА и считать, что ТНК - это коммерческая разновидность НПМО [17]. Если согласиться с этим подходом, то следует признать, что и функционал у ТНК и НПМО должен если не полностью, то хотя бы частично совпадать. Отсюда следует, что из анализа политических функций НПМО можно вывести аналогичный функционал ТНК.

НПМО, в отличие от МПМО, довольно затруднительно утверждать свои интересы в политической сфере: они не обладают международной правосубъектностью, присущей межправительственным международным организациям; «их учредителями являются не государства, а частные организации, учреждения, институты»; «принимаемые ими решения не имеют для государств обязательной (юридической) силы»; «основным средством давления НПМО в сфере международной политики является мобилизация международного общественного мнения» [16]. Не имея возможности воздействовать на сферу международных отношений напрямую, как это делают государства, НПМО используют альтернативный инструментарий, носящий гибридный характер (сочетающий политические инструменты с неполитическими) и не раздражающий национальные правительства, рассматривающие любое «вторжение» в сферу мировой политики НГА как прямое посягательства на их монопольное ведение течением и состоянием дел в системе международных отношений.

По мнению Е.М. Шагабиевой, «главная функция международных неправительственных организаций заключается в установлении связей между государствами и негосударственными сегментами» [16]. Это не совсем так: вопросы государственно-частного партнерства в деятельности НПМО не являются основными, хотя им и придается большое значение. В сфере мировой политики функции МНПО как особого вида политических акторов в целом не намного расходятся с функциями МПМО: неправительственные международные организации продвигают и утверждают в сфере мировой политики свои политические интересы, используя особые инструменты, доступные негосударственным акторам и, при этом, не монополизированные нациями-государствами. Причиной особого выбора инструментов политического воздействия является то, что НМПО не обладают международной правосубъектностью, придающей им статус субъекта международного права и, как следствие, способность обладать правами и обязанностями, следующими из международного права, и вступать в международно-правовые отношения, регулируемые международным правом. НПМО, за единственным исключением, не обладают международной правосубъектностью, поскольку их учре- 
дителями и членами не являются государства, их союзы и коалиции, или МПМО.

Е.М. Шагабиева выделяет следующие функции международных неправительственных организаций: «коммуникативная (отвечает за установление связей между государствами и негосударственными сегментами МO); информационная (НПМО направляют информацию государствам, межправительственным организациям и их органам в сфере своей деятельности); правотворческая (НПМО участвуют в правотворческом процессе, влияя на позицию государств, разрабатывая проекты соглашений); контрольная (НПМО следят за соблюдением норм международного права в различных сферах деятельности); следственная (НПМО создают «независимые» следственные комиссии для расследования нарушений» [16]. Этот перечень функций НПМО немногим отличается от приведенного выше перечня функция МПМО, с которым, в свою очередь, довольно сильно коррелируют политические функции ТНК. Очевидно, что все рассматриваемые категории акторов (и государственных, таких как МПМО, и негосударственных, таких как НПМО) выполняют в мировом политическом пространстве примерно одинаковые (схожие) функции, но возможности у них для этого (и инструментарий, которым они пользуются) существенно различаются.

С нашей точки зрения, функции ТНК в мировой политике могут быть определены и классифицированы следующим образом:

- регулятивная;

- стабилизирующая;

- интеграционная;

- мобильная;

- информационно-коммуникационная;

- сигнальная;

- модернизационная.

Регулятивная функция ТНК заключается в том управляющем воздействии, которое оказывают ТНК на систему международных отношений и мировой политики. ТНК активно включаются в мировые политические процессы, в которых они выступают одновременно и как субъект, и как инструмент политического регулирования. Следствием этого является рост роли ТНК в мировых политических процессах.

Стабилизирующая функция ТНК состоит в том, что ТНК, имеющие транснациональные интересы, часто предпринимают колоссальные усилия для стабилизации внутренней ситуации в тех странах, где у них расположены активы, и для замирения враждующих сторон в локальных международных конфликтах, если эти конфликты вредят бизнесу. Во многих случаях интересы ТНК оказываются выше и крупнее частных интересов наций-го- сударств, толкающих последние на участие в конфликтах. Кроме того, ТНК часто берут на себя роль посредников в переговорах враждующих сторон, а также предоставляют собственные площадки для проведения подобного рода переговоров «на нейтральной территории». Правда, бывает и обратное: в некоторых случаях ТНК, преследуя собственные бизнес-интересы, провоцируют политическую нестабильность в стране. Именно поэтому интересы ТНК часто называют «хищническими», поскольку, в отличие от наций-государств, они начисто лишены идеалистической компоненты.

Интеграционная функция ТНК в мировой политике заключается в том, что ТНК выступают фактором и инструментом развития глобализационные процессов; они объединяют ресурсы и капитал в различных странах, повышают взаимосвязь и взаимозависимость различных политических субъектов и процессов, способствуют интернационализации и движению капитала, ускоряют мировую политическую динамику, помогают встраивать отношения и устанавливать каналы взаимодействия (как формальные, так и неформальные) между государственными акторами МО. Часто ТНК становятся настоящим связующим звеном между государствами в реализации ими того или иного глобального проекта. ТНК обладают большими интеграционными возможностями в силу способности объединять в своей структуре как коммерческие, так и политические элементы, находящиеся под юрисдикцией различных государств - причем основой таких объединений служат миссия ТНК, глобальные цели (стратегические и тактические), глобальное мировоззрение, не ограниченное национальным самосознанием элиты отдельно взятого государства, корпоративные ценности, разделяемые многонациональным менеджментом и сотрудниками ТНК, и, в определенной мере, космополитизм. ТНК выступают ключевыми субъектами, институтами, инициаторами ТТИП и ТТП, формально находясь при этом в тени национальных правительств; различные зоны свободной торговли - это тоже результат деятельности (в том числе политической) ТНК. Наконец, критическая реакция на глобальную деятельность ТНК - движение антиглобалистов - также являются в определённой мере интеграционным процессом, объединяющим противников глобализации в том виде, в котором ее продвигают и реализуют ТНК. Необходимость противостоять единым фронтом натиску транснациональных корпораций вынуждает антиглобалистов также объединять свои усилия, то есть деятельность ТНК порождает интеграционные процессы и в той части мира, которая считает себя альтернативой процессам всеобщей глобализации. 
Мобильная функция ТНК состоит в способности ТНК перебрасывать в различные части мира капитал (интернационализированный, в первую очередь), трудовые и иные ресурсы, которые необходимы, в том числе, и для реализации политических проектов. В политике ТНК часто выступают как каналы передачи управляющего политического воздействия, как каналы распространения (транзита) мягкой силы, информационно-психологического воздействия (пропаганды, например) и т.д. Для этого ТНК используют создаваемые ими транснациональные коммуникационные сети, которые могут использоваться и в политических целях. По мнению транснационалистов (Д. Най-мл., Р. Кохейн), эти сети «формируются вне зависимости от территориальных границ государства и находятся за пределами контроля его центральных органов» [17][18]. Кроме того, ТНК обладают собственными возможностями (механизмами, технологиями) мобилизации транснациональных и трансграничных ресурсов, необходимых для политической борьбы, и делают это нередко лучше и быстрее, чем нациигосударства с их сложноорганизованной и инертной национальной бюрократией.

Информационно-коммуникационная функция ТНК в основном совпадает с аналогичными функциями межправительственных международных организаций, описанных выше. Разница лишь в способах получения информации, которыми обладают ТНК: для этого они используют коммерческие сети, предназначенные для обслуживания транснациональных бизнес-проектов и для дистанционного управления распределенными бизнес-активами.

Сигнальная функция ТНК состоит в том, что довольно часто именно ТНК для международных организаций (таких как ООН) становятся тем источником информации, из которого они черпают информацию о возникновении противоречий между нациями-государствами, способными, в случае их укоренения, привести к возникнове- нию международного конфликта. ТНК покрывают сферу мировой политики своей диагностической сетями, выявляющими и распознающими малейшие признаки политической нестабильности в тех регионах, где сосредоточены из бизнес-интересы. Эти сети состоят из «ячеек, объединенных друг с другом нитями трансграничных связей; они формируются помимо государств на всех уровнях - от локального до глобального [19][20]. При достижении определенных договоренностей эту информацию начинают получать и секретариаты $\mathrm{OOH}$ и некоторые (лояльные к деятельности ТНК) национальные правительства. ТНК ведут мониторинг состояния международной безопасности, и данными этого мониторинга не стоит пренебрегать.

Модернизационная функция ТНК в мировой политике заключается в том, что ТНК, будучи сами «нетрадиционными» для сферы международных отношений акторами, привносят в сферу глобальной политики много нового, как в формах, так и в методах управления политическими процессами. ТНК вынуждены это делать: они не обладают суверенитетом, не могут сравняться в статусе с нациями-государствами, изначально ограничены - в силу перечисленных выше факторов - в политических возможностях и поэтому компенсируют эти недостатки, используя собственный, инновационный арсенал инструментов и технологий политического воздействия. Вот почему ТНК нередко становятся источником инноваций в мировой политике, новых и нетрадиционных («гибридных» [21]) подходов, которые в определённой мере меняют существующую политическую реальность и под которые нации-государства, более консервативные в выборе инструментов политического воздействия, вынуждены подстраиваться. В результате сфера мировой политики под воздействием «вторжения» в нее ТНК начинает меняться, мутировать, модернизироваться. И это - фактор, отчасти определяющей характер и направление эволюции мировой политики в целом.

\section{Библиография:}

1. Цыганков П.А. О содержании термина «международный актор»: вклад социологии // Пространство и время в мировой политике и международных отношениях. Материалы 4-го Конвента Российской ассоциации международных исследований. В 10 т. Т. 1: Акторы в пространстве и времени мировой политики / Под общ. ред. А.Ю. Мельвиля; ред. тома М.М. Лебедева. М.: МГИМО-Университет, 2007. С. 90.

2. Башкиров Н. Опыт использования частных военных компаний в ходе военных конфликтов в Ираке и Афганистане // Зарубежное военное обозрение. 2013. № 11. С. 11-21.

3. Francioni F. The Responsibility of the PMSC's Home State for Human Rights Violations Arising from the Export of Private Military and Security Services // Academy of European Law, Project "Regulating Privatization of "War": The Role of the EU in Assuring the Compliance with International Humanitarian Law and Human Rights”. 2009. p. 6.

4. Private soldiers. Bullets for hire. [Электронный документ] / The Economist, 2012, 17 ноя. URL: http://www.economist. com/news/international/21566625-business-private-armies-not-only-growing-changing-shape-bullets-hire (Дата обращения 12.06.2016)

5. Серков С. Становление современной отрасли частной безопасности и его последствия для международного гуманитарного права. [Электронный документ] / 2013, 1 ноя. URL: http://uriadnik.livejournal.com/104288.html (Дата обращения 12.06.2016) 
6. Zorgbibe Ch. Les organisations internationals / Zorgbibe Ch. R., 1991. p. 91-118.

7. Кутейников А.Е. Международные межправительственные организации: теоретико-социологический анализ. СПб.: Изд-во С.-Петерб. ун-та, 2012. 256 с.

8. «Приватизация» мировой политики / Под ред. М.М. Лебедевой. М., 2008. С. 90.

9. Маляр Д. Кому выгодно Трансатлантическое торговое и инвестиционное партнерство? [Электронный документ] / FB.ru, 2016, 4 мая. URL: http://fb.ru/news/economics/2016/5/4/5314 (Дата обращения 12.07.2016)

10. Королева И.С. Мировая экономика: глобальные тенденции за 100 лет. М.: Экономист, 2007. С. 55.

11. https://www.stratfor.com/ (Дата обращения 12.07.2016)

12. Манойло А.В. Кто стоит за гражданской войной в Южном Судане // Мир и политика. 2011. № 5. С. 82-96.

13. Не чужая беда. Ринат Ахметов финансирует гуманитарные поставки в отрезанный от Украины Донбасс. [Электронный документ] / Российская газета. 2015, 15 июн. URL: (Дата обращения 12/07/2016)

14. Trade In Services, Investment and E-Commerce. Draft. [Электронный документ] / 2013, 2 июл. URL: http://keionline. org/sites/default/files/eu-kommission-position-in-den.pdf (Дата обращения 12.06.2016)

15. Идаятов А.К. Медиакратия и ее роль в регулировании политических конфлкитов (на примере российско-грузинского конфликта 2008 года). Автореф. дисс. ... канд. полит. наук. М.: МГУ, 2014. С 76.

16. Шагабиева Е.М. Международные неправительственные организации: их виды, особенности, категории и характеристика // Власть. 2010. С. 94-96.

17. Голикова Ю.А. Транснациональные корпорации: определение сущности и характеристика деятельности в современных условиях // Вестник НГУ. Серия: социально-экономические науки, Т.10, вып. 4, 2010. С. 32-39.

18. Шагабиева Е.М. Международные неправительственные организации: их виды, особенности, категории и характеристика // Власть. 2010. С. 94-96.

19. Най Дж. Гибкая сила. Как добиться успеха в мировой политике. М.: Тренд, 2006. 397 с.

20. Keohane R. O. And Nye J. S. (Jr) Ed. Transnational Relations and World Politics. Cambridge. MA: Harvard University Press, 1972.

21. Цыганков П.А. Мировая политическая динамика современного мира. Теория и практика. М.: Издательство Московского университета, 2014. (Библиотека факультета политологии МГУ). С. 52.

22. Манойло А.В. Политические конфликты в международных отношениях и мировой политике // Мир и Политика. 2013. № 2. С. 71-82.

23. Филиппов В.Р. Реформирование российской государственности: политизация этничности или деэтнизация политики? // Казанский федералист. 2002. № 1. С. 17-35.

24. Карпович О.Г. Интересы США в Украинском кризисе 2013-14-х гг.: основные выгоды и преимущества // Политика и Общество. 2016. № 8. С. 1039 - 1048. DOI: 10.7256/1812-8696.2016.8.19468.

25. Денчев С., Павлова М. Цветные революции: Кто смешивает краски и кто художник? // Конфликтология / поta bene. 2016. № 1. C. 5 - 10. DOI: 10.7256/2409-8965.2016.1.18498.

26. Бочарников И.В. Современные тенденции развития международного терроризма // Конфликтология / пота bene. 2016. № 1. С. 52 - 61. DOI: 10.7256/2409-8965.2016.1.17852.

27. Манойло А.В. Модели «мягкой силы» сетевых террористических организаций (на примере запрещенных в Российской Федерации «Исламского государства», Аль-Кайды, Талибана и «Братьев-мусульман») // Конфликтология / nota bene. 2016. № 1. C. 11 - 19. DOI: 10.7256/2409-8965.2016.1.18626.

28. Иванов С.М. Сепаратизм - естественный процесс или угроза национальной и международной безопасности? // Конфликтология / nota bene. 2016. 1. C. 62 - 71. DOI: 10.7256/2409-8965.2016.1.17856.

29. Филиппов B.P. Тайная война Франции в Биафре // Политика и Общество. 2016. № 3. C. 285-300. DOI: 10.7256/18128696.2016.3.18323.

30. Манойло А.В. К вопросу о моделях и механизмах выработки политических решений в Российской Федерации // Тренды и управление. 2016. № 1. C. 45 - 49. DOI: 10.7256/2307-9118.2016.1.18001.

31. Карпович О.Г. «Мягкая сила» бразильской модели федерализма // Политика и Общество. 2016. № 2 . С. 164 - 171. DOI: $10.7256 / 1812-8696.2016 .2 .17128$.

32. Гушер А.И. Геополитические и стратегические аспекты операции Воздушно-космических сил России в Сирии // Конфликтология / nota bene. - 2015. - 4. - С. 395 - 402. DOI: 10.7256/2409-8965.2015.4.16967.

33. Бочарников И.В. Политологические аспекты борьбы с коррупцией // Конфликтология / nota bene. - 2015. - 4. - С. 374 - 381. DOI: 10.7256/2409-8965.2015.4.17441.

34. Карякин В.В. Политическая медиаметрия: книга о том, как четвертая власть правит миром // Конфликтология / nota bene. - 2016. - 1. - C. 86 - 89. DOI: 10.7256/2409-8965.2016.1.17755.

35. Карпович О.Г. Сепаратизм и сепаратистские движения в современном мире (на примере Бельгии и Великобритании): сравнительный анализ // Право и политика. 2016. № 4. С. 449-457. DOI: 10.7256/1811-9018.2016.4.18693.

36. Бочарников И.В. Террористическая группировка «Исламское государство» как закономерное следствие ближневосточной стратегии США // Тренды и управление. - 2015. - 4. - C. 395 - 402. DOI: 10.7256/2307-9118.2015.4.17007.

37. Доброхотов Л.Н. Взлет и падение Марко Рубио как итог первого этапа выборной кампании 2016 года в США // Мировая политика. - 2016. - 2. - С. 17 - 26. DOI: 10.7256/2409-8671.2016.2.18758. URL: http://www.e-notabene.ru/ wi/article_18758.html

\section{References (transliterated):}

1. Tsygankov P.A. O soderzhanii termina «mezhdunarodnyi aktor»: vklad sotsiologii // Prostranstvo i vremya v mirovoi politike i mezhdunarodnykh otnosheniyakh. Materialy 4-go Konventa Rossiiskoi assotsiatsii mezhdunarodnykh issledovanii. V 10 t. T. 1: Aktory v prostranstve i vremeni mirovoi politiki / Pod obshch. red. A.Yu. Mel'vilya; red. toma M.M. Lebedeva. M.: MGIMO-Universitet, 2007. S. 90.

2. Bashkirov N. Opyt ispol'zovaniya chastnykh voennykh kompanii v khode voennykh konfliktov v Irake i Afganistane // Zarubezhnoe voennoe obozrenie. 2013. № 11. S. 11-21. 
3. Francioni F. The Responsibility of the PMSC's Home State for Human Rights Violations Arising from the Export of Private Military and Security Services // Academy of European Law, Project "Regulating Privatization of "War": The Role of the EU in Assuring the Compliance with International Humanitarian Law and Human Rights". 2009. p. 6.

4. Private soldiers. Bullets for hire. [Elektronnyi dokument] / The Economist, 2012, 17 noya. URL: http://www.economist. $\mathrm{com} /$ news/international/21566625-business-private-armies-not-only-growing-changing-shape-bullets-hire (Data obrashcheniya 12.06.2016)

5. Serkov S. Stanovlenie sovremennoi otrasli chastnoi bezopasnosti i ego posledstviya dlya mezhdunarodnogo gumanitarnogo prava. [Elektronnyi dokument] / 2013, 1 noya. URL: http://uriadnik.livejournal.com/104288.html (Data obrashcheniya 12.06.2016)

6. Zorgbibe Ch. Les organisations internationals / Zorgbibe Ch. R., 1991.p. 91-118.

7. Kuteinikov A.E. Mezhdunarodnye mezhpravitel'stvennye organizatsii: teoretiko-sotsiologicheskii analiz. SPb.: Izd-vo S.Peterb. un-ta, 2012.256 s.

8. «Privatizatsiya» mirovoi politiki / Pod red. M.M. Lebedevoi. M., 2008. S. 90.

9. Malyar D. Komu vygodno Transatlanticheskoe torgovoe i investitsionnoe partnerstvo? [Elektronnyi dokument] / FB.ru, 2016, 4 maya. URL: http://fb.ru/news/economics/2016/5/4/5314 (Data obrashcheniya 12.07.2016)

10. Koroleva I.S. Mirovaya ekonomika: global'nye tendentsii za 100 let. M.: Ekonomist, 2007. S. 55.

11. https://www.stratfor.com/ (Data obrashcheniya 12.07.2016)

12. Manoilo A.V. Kto stoit za grazhdanskoi voinoi v Yuzhnom Sudane // Mir i politika. 2011. № 5. S. 82-96.

13. Ne chuzhaya beda. Rinat Akhmetov finansiruet gumanitarnye postavki v otrezannyi ot Ukrainy Donbass. [Elektronnyi dokument] / Rossiiskaya gazeta. 2015, 15 iyun. URL: (Data obrashcheniya 12/07/2016)

14. Trade In Services, Investment and E-Commerce. Draft. [Elektronnyi dokument] / 2013, 2 iyul. URL: http://keionline.org/ sites/default/files/eu-kommission-position-in-den.pdf (Data obrashcheniya 12.06.2016)

15. Idayatov A.K. Mediakratiya i ee rol' v regulirovanii politicheskikh konflkitov (na primere rossiisko-gruzinskogo konflikta 2008 goda). Avtoref. diss. ... kand. polit. nauk. M.: MGU, 2014. S 76.

16. Shagabieva E.M. Mezhdunarodnye nepravitel'stvennye organizatsii: ikh vidy, osobennosti, kategorii i kharakteristika // Vlast'. 2010. S. 94-96.

17. Golikova Yu.A. Transnatsional'nye korporatsii: opredelenie sushchnosti i kharakteristika deyatel'nosti v sovremennykh usloviyakh // Vestnik NGU. Seriya: sotsial'no-ekonomicheskie nauki, T.10, vyp. 4, 2010. S. 32-39.

18. Shagabieva E.M. Mezhdunarodnye nepravitel'stvennye organizatsii: ikh vidy, osobennosti, kategorii i kharakteristika // Vlast'. 2010. S. 94-96.

19. Nai Dzh. Gibkaya sila. Kak dobit'sya uspekha v mirovoi politike. M.: Trend, 2006. $397 \mathrm{~s}$.

20. Keohane R. O. And Nye J. S. (Jr) Ed. Transnational Relations and World Politics. Cambridge. MA: Harvard University Press, 1972.

21. Tsygankov P.A. Mirovaya politicheskaya dinamika sovremennogo mira. Teoriya i praktika. M.: Izdatel'stvo Moskovskogo universiteta, 2014. (Biblioteka fakul'teta politologii MGU). S. 52.

22. Manoilo A.V. Politicheskie konflikty v mezhdunarodnykh otnosheniyakh i mirovoi politike // Mir i Politika. 2013. № 2. S. 71-82.

23. Filippov V.R. Reformirovanie rossiiskoi gosudarstvennosti: politizatsiya etnichnosti ili deetnizatsiya politiki? // Kazanskii federalist. 2002. № 1. S. 17-35.

24. Karpovich O.G. Interesy SShA v Ukrainskom krizise 2013-14-kh gg.: osnovnye vygody i preimushchestva // Politika i Obshchestvo. 2016. № 8. C. 1039 - 1048. DOI: 10.7256/1812-8696.2016.8.19468.

25. Denchev S., Pavlova M. Tsvetnye revolyutsii: Kto smeshivaet kraski i kto khudozhnik? // Konfliktologiya / nota bene. 2016. № 1. C. 5 - 10. DOI: 10.7256/2409-8965.2016.1.18498.

26. Bocharnikov I.V. Sovremennye tendentsii razvitiya mezhdunarodnogo terrorizma // Konfliktologiya / nota bene. 2016. № 1. C. 52 - 61. DOI: 10.7256/2409-8965.2016.1.17852.

27. Manoilo A.V. Modeli «myagkoi sily» setevykh terroristicheskikh organizatsii (na primere zapreshchennykh v Rossiiskoi Federatsii «Islamskogo gosudarstva», Al'-Kaidy, Talibana i «Brat'ev-musul'man») // Konfliktologiya / nota bene. 2016. № 1. C. 11 - 19. DOI: 10.7256/2409-8965.2016.1.18626

28. Ivanov S.M. Separatizm - estestvennyi protsess ili ugroza natsional'noi i mezhdunarodnoi bezopasnosti? // Konfliktologiya / nota bene. 2016. 1. C. 62 - 71. DOI: 10.7256/2409-8965.2016.1.17856.

29. Filippov V.R. Tainaya voina Frantsii v Biafre // Politika i Obshchestvo. 2016. № 3. C. 285-300. DOI: 10.7256/18128696.2016.3.18323.

30. Manoilo A.V. K voprosu o modelyakh i mekhanizmakh vyrabotki politicheskikh reshenii v Rossiiskoi Federatsii // Trendy i upravlenie. 2016. № 1. C. 45 - 49. DOI: 10.7256/2307-9118.2016.1.18001.

31. Karpovich O.G. «Myagkaya sila» brazil'skoi modeli federalizma // Politika i Obshchestvo. 2016. № 2. C. 164 - 171. DOI: 10.7256/1812-8696.2016.2.17128.

32. Gusher A.I. Geopoliticheskie i strategicheskie aspekty operatsii Vozdushno-kosmicheskikh sil Rossii v Sirii // Konfliktologiya / nota bene. - 2015. - 4. - C. 395 - 402. DOI: 10.7256/2409-8965.2015.4.16967.

33. Bocharnikov I.V. Politologicheskie aspekty bor'by s korruptsiei // Konfliktologiya / nota bene. - 2015. - 4. - C. 374 - 381. DOI: 10.7256/2409-8965.2015.4.17441.

34. Karyakin V.V. Politicheskaya mediametriya: kniga o tom, kak chetvertaya vlast' pravit mirom // Konfliktologiya / nota bene. - 2016. - 1. - C. 86 - 89. DOI: 10.7256/2409-8965.2016.1.17755.

35. Karpovich O.G. Separatizm i separatistskie dvizheniya v sovremennom mire (na primere Bel'gii i Velikobritanii): sravnitel'nyi analiz // Pravo i politika. 2016. № 4. C. 449-457. DOI: 10.7256/1811-9018.2016.4.18693.

36. Bocharnikov I.V. Terroristicheskaya gruppirovka «Islamskoe gosudarstvo» kak zakonomernoe sledstvie blizhnevostochnoi strategii SShA // Trendy i upravlenie. - 2015. - 4. - C. 395 - 402. DOI: 10.7256/2307-9118.2015.4.17007.

37. Dobrokhotov L.N. Vzlet i padenie Marko Rubio kak itog pervogo etapa vybornoi kampanii 2016 goda v SShA // Mirovaya politika. - 2016. - 2. - C. 17 - 26. DOI: 10.7256/2409-8671.2016.2.18758. URL: http://www.e-notabene.ru/wi/ article_18758.html 